\title{
A phytosociology survey and vegetation description of inselbergs in the uKhahlamba-Drakensberg Park World Heritage Site, South Africa
}

\begin{tabular}{|c|c|}
\hline \multicolumn{2}{|c|}{$\begin{array}{l}\text { Authors: } \\
\text { Robert F. Brand }{ }^{1} \\
\text { Nacelle Collins }{ }^{2} \\
\text { P. Johann du Preez }\end{array}$} \\
\hline \multicolumn{2}{|c|}{$\begin{array}{l}\text { Affiliations: } \\
{ }^{1} \text { Applied Behavioural Ecology } \\
\text { \& Ecosystem Research Unit, } \\
\text { University of South Africa, } \\
\text { South Africa }\end{array}$} \\
\hline \multicolumn{2}{|c|}{$\begin{array}{l}{ }^{2} \text { Free State Department of } \\
\text { Economic Development, } \\
\text { Tourism and Environmental } \\
\text { Affairs, Free State, } \\
\text { South Africa }\end{array}$} \\
\hline \multicolumn{2}{|c|}{$\begin{array}{l}{ }^{3} \text { Department of Plant } \\
\text { Sciences, University of the } \\
\text { Free State, South Africa }\end{array}$} \\
\hline \multicolumn{2}{|c|}{$\begin{array}{l}\text { Correspondence to: } \\
\text { Robert Brand }\end{array}$} \\
\hline \multicolumn{2}{|c|}{$\begin{array}{l}\text { Email: } \\
\text { rbrand@mweb.co.za }\end{array}$} \\
\hline \multicolumn{2}{|c|}{$\begin{array}{l}\text { Postal address: } \\
\text { Private Bag X6, Florida 1710, } \\
\text { South Africa }\end{array}$} \\
\hline \multicolumn{2}{|c|}{$\begin{array}{l}\text { Dates: } \\
\text { Received: } 15 \text { Apr. } 2014 \\
\text { Accepted: } 10 \text { Sept. } 2014 \\
\text { Published: } 16 \text { Apr. } 2015\end{array}$} \\
\hline \multicolumn{2}{|c|}{$\begin{array}{l}\text { How to cite this article: } \\
\text { Brand, R.F., Collins, N. \& } \\
\text { Du Preez, P.J., 2015, 'A } \\
\text { phytosociology survey and } \\
\text { vegetation description } \\
\text { of inselbergs in the } \\
\text { uKhahlamba-Drakensberg } \\
\text { Park World Heritage Site, } \\
\text { South Africa', Koedoe 57(1), } \\
\text { Art. \#1233, } 12 \text { pages. } \\
\text { http://dx.doi.org/10.4102/ } \\
\text { koedoe.v57i1.1233 }\end{array}$} \\
\hline \multicolumn{2}{|l|}{ Read online: } \\
\hline 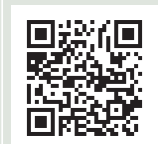 & $\begin{array}{l}\text { Scan this QR } \\
\text { code with your } \\
\text { smart phone or } \\
\text { mobile device } \\
\text { to read online. }\end{array}$ \\
\hline
\end{tabular}

\begin{abstract}
No previous scientific surveys have been conducted on inselbergs in the Drakensberg. The aim of this study was to collect specimens, identify, describe and name the vegetation clusters and assess biogeographical connections with other Afromontane regions. A total of 103 relevés where sampled from six inselbergs. The plant sampling was carried out according to the Braun-Blanquet method with the plant and environmental data entered in TURBOVEG and exported as a Cornell Condensed format file (CC!) into Juice. Classification was completed using TWINSPAN (Two-way Indicator Species Analysis) (modified), resulting in 4 major communities, 11 communities, 13 sub-communities and 18 variants. Ordination (indirect) was carried out using CANOCO (version 4.5) to investigate the relationship between species. The four major communities identified are Rhodohypoxis rubella (wetland grass and forblands), Scirpus ficinioides - Crassula peploides (sheet rock grass and forblands), Pentaschistis exserta (high-altitude alpine grassland), previously undescribed, and Merxmuellera drakensbergensis - Helichrysum trilineatum (high-altitude alpine fynbos grassland), described in other vegetation and floristic studies. Four habitats were identified, namely wetlands, sheet rock shallow soil, highaltitude alpine grassland and deep soil high-altitude fynbos grasslands. Substrate and moisture availability appeared to be the defining micro-climatic conditions determining the different vegetation clusters whilst altitude is the overriding environmental factor influencing all vegetation.

Conservation implications: Rising temperatures as a result of carbon dioxide increase is predicted to drastically decrease the number of endemic and near-endemic montane species, whilst altering the composition of vegetation units which comprise the alpine vegetation.
\end{abstract}

\section{Introduction}

Studies of high-altitude inselbergs within the east and southern Afromontane region are few. Whilst studies of inselbergs in Africa have been concentrated more in West Africa (Barthlott, Gröger \& Porembski 1993; Parmentier et al. 2006; Porembski \& Brown 1995; Porembski et al. 1996, 1997; Seine et al. 1998), several have been undertaken in Namibia (Burke 2001, 2002, 2004) and South Africa, such as with the Korannaberg (Du Preez 1991) and Platberg, at 2394.5 m, some $60 \mathrm{~km}$ north of the Drakensberg (Brand, Du Preez \& Brown 2010). Other inselberg surveys have been conducted in Moçambique (Van Noort, Gardiner \& Tolley 2007) which document the high biological diversity and establishe inselbergs as sites of high endemism. Many are denoted as biodiversity 'hotspots' (Van Noort et al. 2007), which also represent relictual plant populations of past climate conditions. Climate change and global warming, with its rising carbon dioxide levels, will have a profound impact on the grassland biome and the structure of $C_{3}$ and $C_{4}$ grasses (Mucina \& Rutherford 2006), in particular the alpine grasses embedded in the grassland biome. Inselbergs have also been assessed for their high conservation value and biotic diversity (ed. Huntley 1989).

This article is the first phytosociological survey of the high-altitude inselbergs in the Drakensberg. Its aims are to (1) classify the inselberg alpine vegetation into communities and present the species composition, (2) examine environmental gradients to identify habitats and (3) identify and examine biogeographical affinities with previously described or identified

Note: Additional supporting information may be found in the online version of this article as an Online Appendix: http://dx.doi. org/10.4102/koedoe.v57i1.1233-1.

Copyright: @ 2015. The Authors. Licensee: AOSIS OpenJournals. This work is licensed under the Creative Commons Attribution License. 


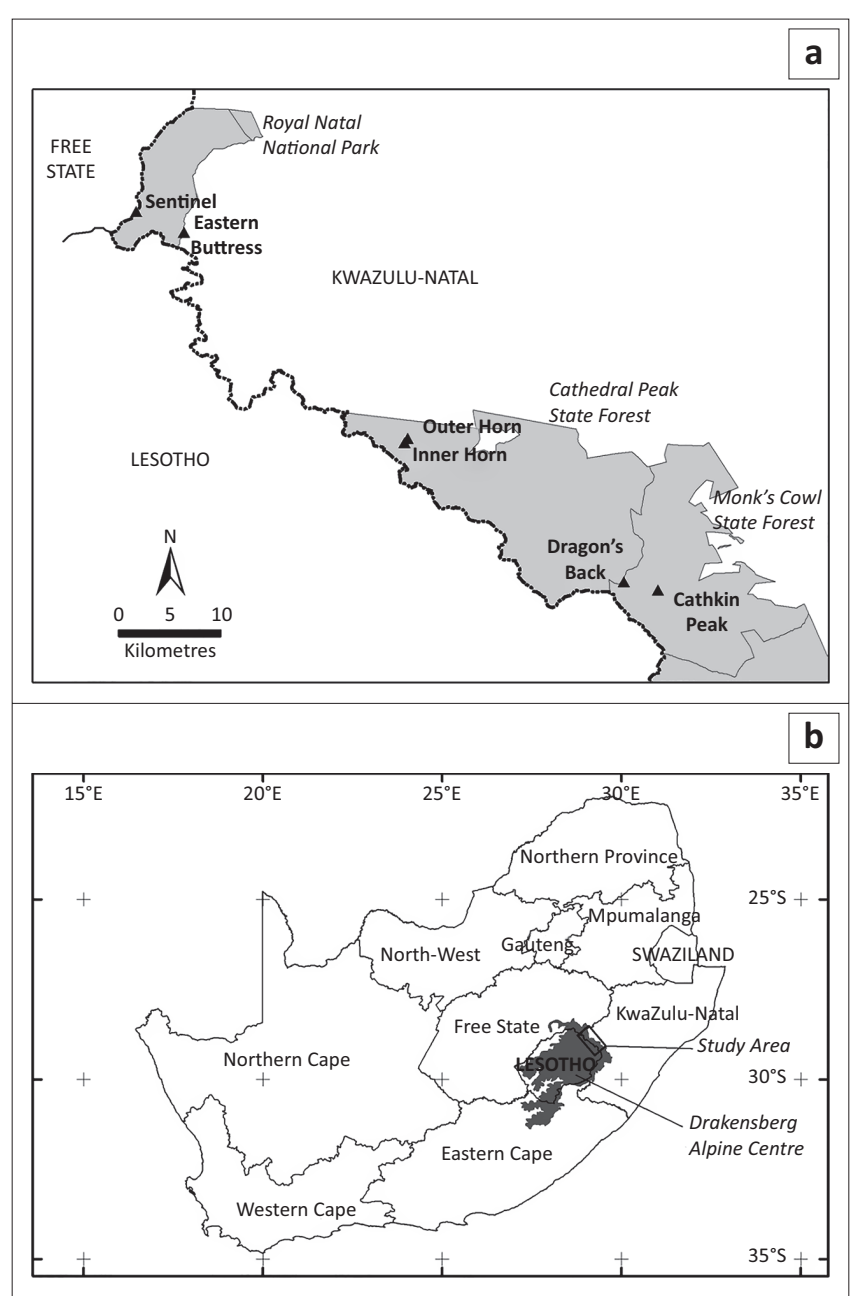

Source: Composed by Heidi Snyman of Ezemvelo KwaZulu-Natal Wildlife

FIGURE 1: Maps of study sites: (a) study area with KwaZulu-Natal uKhahlambaDrakensberg Park (shaded) and (b) South Africa indicating Drakensberg Alpine Centre.

plant communities. This new knowledge will contribute to the understanding and conservation management of high-altitude alpine vegetation and species unique to the Drakensberg.

\section{Study area}

The study sites are located in the Drakensberg, South Africa, and consist of six inselbergs, all over $3000 \mathrm{~m}$ in altitude (Figure 1). The most northerly, Sentinel, is located at $28^{\circ} 44^{\prime} 25.97^{\prime \prime} \mathrm{S}$ and $28^{\circ} 53^{\prime} 27.42^{\prime \prime} \mathrm{E}$, with four inselbergs - Eastern Buttress, Inner Horn, Outer Horn and Dragon's Back - sequentially between it and the most southerly of the inselbergs surveyed, namely Cathkin Peak at $29^{\circ} 4^{\prime} 35.03^{\prime \prime} \mathrm{S}$ and $29^{\circ} 20^{\prime} 59.38^{\prime \prime}$ E. All six peaks fall within the KwaZulu-Natal uKhahlamba-Drakensberg Park, a World Heritage site and part of the Drakensberg Alpine Centre (DAC) biodiversity hotspot. All inselbergs with the exception of Sentinel are relatively flat-topped, with boulders, shallow soils occurring on sheet rock, gravel plains, seeps, interconnected seasonally inundated wetlands and ephemeral pools (Figures 2 and 3). They are all sheer sided, separated by varying distances from the main escarpment by cliffs of $1000 \mathrm{~m}$ or more, and form an archipelago of island-like peaks stretching some $60 \mathrm{~km}$ north to south.

\section{Materials and methods Data collection}

A total of 103 plots where sampled on the six inselbergs. Plot sizes varied according to substrate, and were subjectively estimated at either $3 \mathrm{~m} \times 3 \mathrm{~m}$ for sheet rock, seeps or gravel plains, or $6 \mathrm{~m} \times 5 \mathrm{~m}$ for grass or dwarf shrub vegetation as per theoretical criteria (Westhoff \& Van der Maarel 1980) and established field practice in South Africa (Brown et al. 2013). In all sample plots each species was recorded, all plants counted and cover estimated using the modified Braun-Blanquet cover/abundance scale: $r,+, 1,2 \mathrm{a}, 2 \mathrm{~b}, 3$, 4, 5 (Mueller-Dombois \& Ellenberg 1974; Whitaker 1980). Selection and sampling of vegetation was carried out where a visible difference could be seen in vegetation or where it occurred in clearly different habitats such as rocky outcrops, wetlands, sheet rock or seeps. Fieldwork was carried out in November 2005, with initial identification of known plants carried out in the field and later conducted in the Donald Killick KZN Herbarium (CFR) and the Geo Potts Herbarium (BLFU) at the University of the Free State. More problematic material was identified at the South African National Biodiversity Institute Herbarium (PRE) in Pretoria. Plant species nomenclature was according to Germishuizen et al. (2006), and updated with the November 2009 PRECIS database at the South African National Biodiversity Institute (SANBI), Pretoria. Habitat as well as floristic data was captured using TURBOVEG (Hennekens \& Schaminée 2001), with the subsequent relevés generated exported as a Cornell condensed format file (CC!) into Juice version 7.0.28 (Tichý \& Holt 2006).

\section{Data processing}

A first approximation at clustering was carried out using the TWINSPAN (Two-way Indicator Species Analysis) algorithm of Hill (1979) which is incorporated as part of the Juice program. To produce the syntaxonomic table using Juice, separators were defined at six hierarchical levels, with group size standardised. Using Juice version 7.0.28 (Tichý \& Holt 2006), the diagnostic species were identified by applying a statistical fidelity measurement which is useful for assessment of species concentration in vegetation units, and for comparing diagnostic values amongst species in a particular vegetation unit, or amongst vegetation units for a particular species (Tichý \& Holt 2006). Fidelity values were calculated using the phi coefficient, which considers only presence/absence data, so that the fidelity values are not influenced by the cover/abundance values of the species (Lepš \& Hadincová 1992). The Fisher's exact test was employed along with the phi coefficient fidelity measure to calculate the true probability of obtaining the observed number of occurrences of the species in the vegetation unit under the null hypothesis of independence. Using the Fisher's exact test along with the phi coefficient measure of fidelity causes values that are not statistically significant 

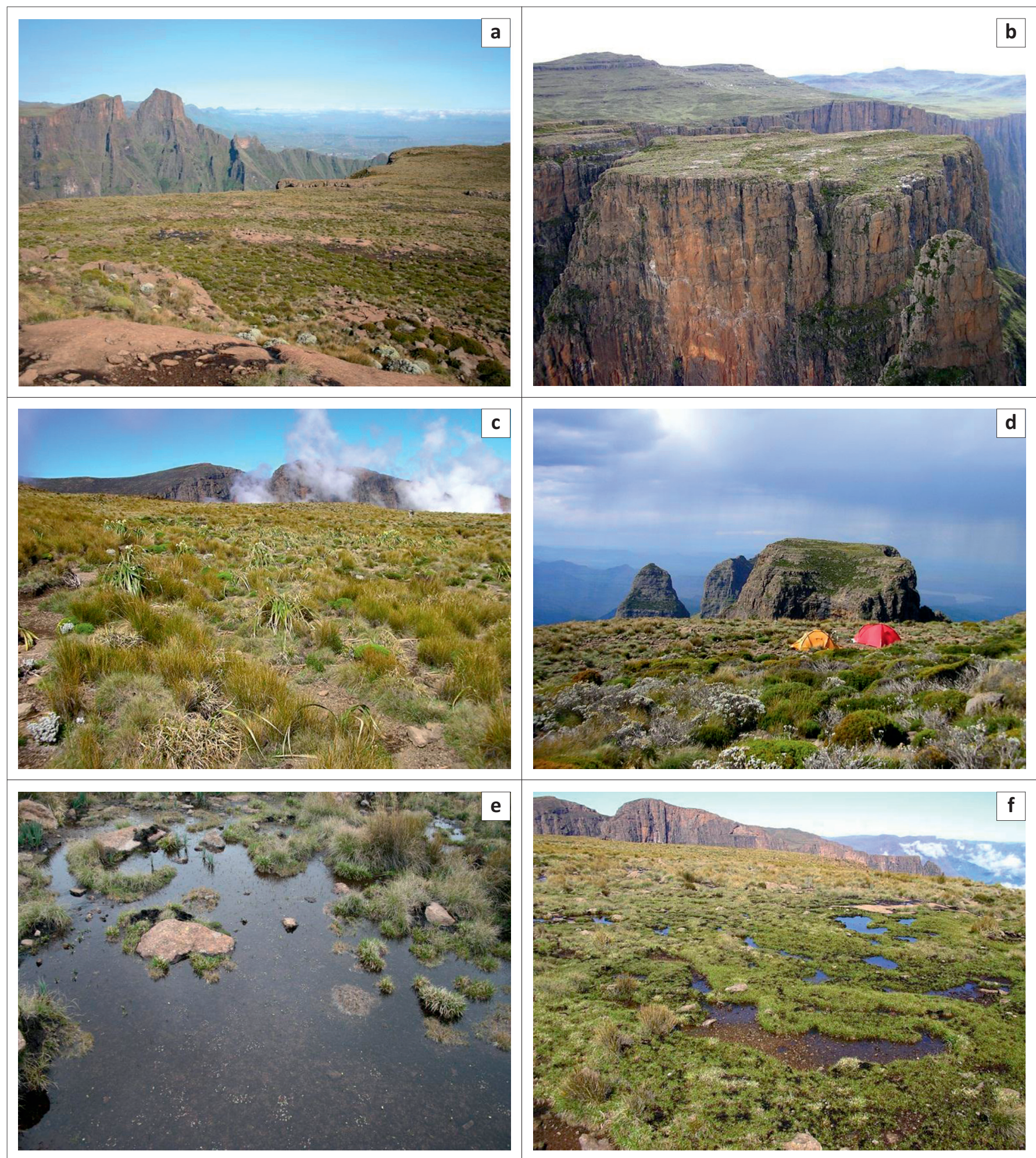

Source: Photographs are courtesy of Richard Lechemere-Oertel, Boyd Escort and Rob Scott-Shaw

FIGURE 2: Photographs of inselberg vegetation in the Drakensberg: (a) typical inselberg vegetation of low, cushion-forming fynbos shrubs and bunch grass on Outer Buttress, with the sloping peak of Sentinel in the background, (b) the flat top of Inner Buttress showing three of the four habitats: sheet rock outcrops/gravel plains, alpine grasslands and deep soil, Helichrysum/Erica fynbos grassland. Devils tooth in the foreground, (c) tall, montane grass community: Merxmuellera drakensbergensis, Erica dominans and the yellow-flowering Moraea alticola, (d) deep soil habitat of the yellow-flowering Helichrysum trilineatum, Erica species and Passerina drakensbergensis with typical caespitose habitat, indicative of alpine conditions, (e) Wetland habitat, with Aponogeton ranunculiflorus the Drakensberg Alpine Centre endemic, hydrophyte, an ephemeral-pool specialistn and (f) mixed habitats on Cathkin of wetlands, gravel seeps, sheet rock shallow soils, embedded in rocky terrain with alpine grasslands and the Helichrysum/Erica fynbos.

at the predefined $p$-value to be assigned a fidelity value of 0 , where $p$ was chosen to be $<0.001$. Species are therefore only identified as diagnostic if their fidelity values exceed the subjectively chosen lower threshold. The Braun-Blanquet normal scale was used, and a combination of frequency, fidelity and cover was selected, using the default settings of $67 \%$ frequency and $45.3 \%$ fidelity. Despite the subjectivity and inaccuracy of the Braun-Blanquet method and the use 


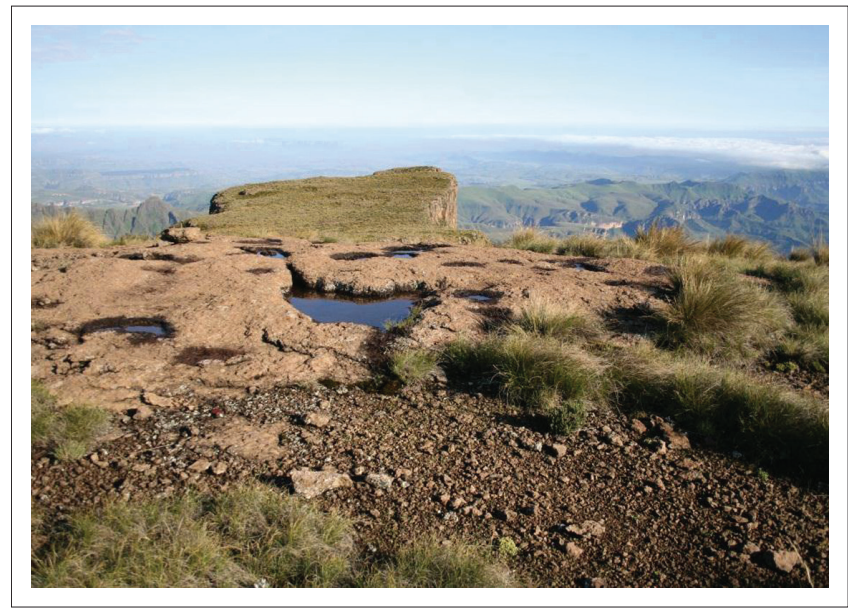

Source: Photographs are courtesy of Richard Lechemere-Oertel, Boyd Escort and Rob ScottShaw

FIGURE 3: Uncommon vernal pools on Cathkin and Outer Buttress, habitat for specialist aquatic plants Aponogeton junceus, Crassula dependens, Crassula gemmifera, Limosella grandiflora and Limosella vesiculosa.

of non-numerical scores ' $r$ ' and ' + ', which pose computation problems discussed in detail by Podani (2006), this method of field data collection was used to conform with and make this survey's data compatible with the thousands of relevés already sampled in South Africa. The continued use of the Braun-Blanquet method in South Africa is also suggested by Brown et al. (2013).

\section{Classification}

Within Juice the lower threshold values for the diagnostic, constant and dominant species when applying the 'Analysis of columns of syntaxonomic tables' (Tichý \& Holt 2006) function were set to 70,60 and 50 respectively, whilst the upper threshold values were set to 80,70 and 60 respectively. Species that exceed the lower threshold are listed whilst those that exceed the upper threshold are printed in bold.

\section{Naming of plant communities}

The naming of plant communities was carried out according to guidelines suggested by Brown et al. (2013). The syntaxonomic names for the major communities, communities, sub-communities and variants were derived according to diagnostic, dominant and constant species obtained from floristic and environmental data processed in Juice (Tichý \& Holt 2006).

\section{Gradient analysis}

The skewness and kurtosis calculations performed with PC-ORD version 5.0 revealed the non-unimodal distribution of the species data (also confirmed by the disjunct nature of the dataset as indicated by the DCA eigenvalue of one for the first axis) (Gauch 1982a, 1982b). To achieve a normal distribution the species data were log-transformed during ordination (Legendre \& Legendre 1998).

A final manipulation of relevé columns and species rows was carried out in Juice to fine-tune the phytosociological table,

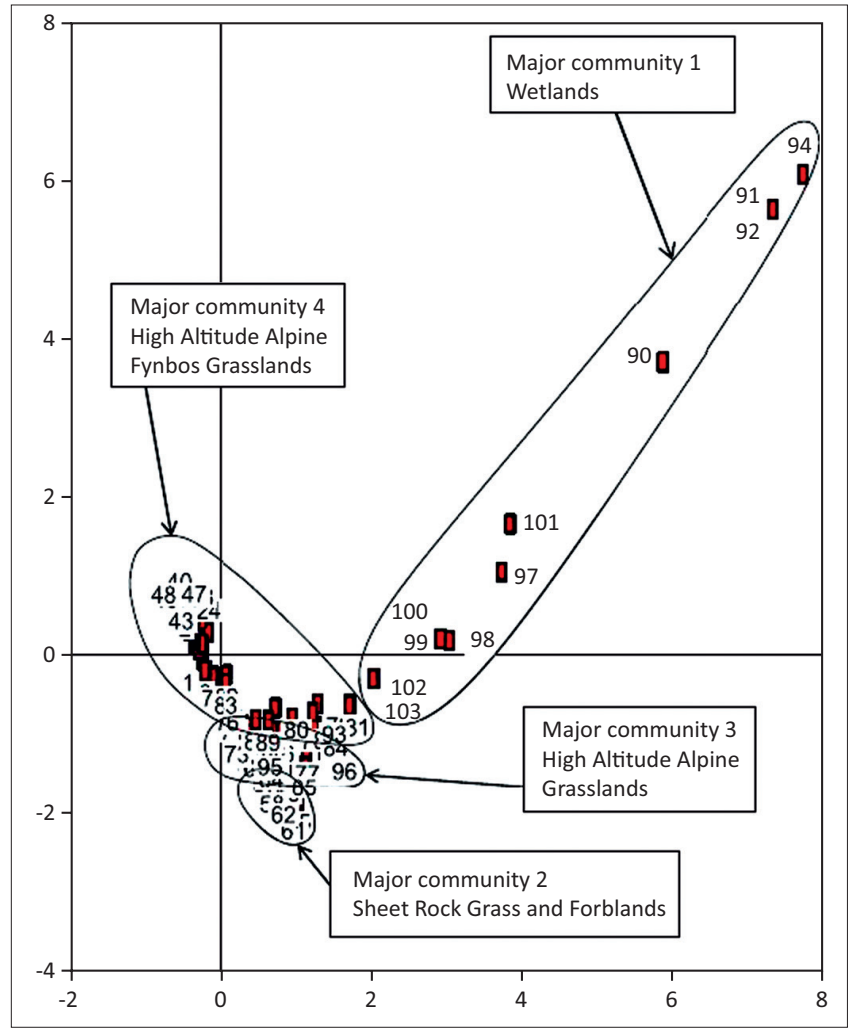

Source: Authors' own creation

Note: Axis 1: horizontal; Axis 2: minor vertical.

FIGURE 4: Correspondence analysis of all relevés showing major communities $1,2,3$ and 4 .

which was exported into Excel and refined for presentation by moving rows containing species and adding alphabetic letters to denote species groups (Online Appendix 1). Groups of similar ecological characteristics were identified and related to environmental gradients. The relationship of the identified plant communities with the environmental variables is presented in Figures 4 and 5.

\section{Results}

\section{Species composition}

A total of 103 relevés and 189 species where incorporated in the classification; $2.6 \%$ of these were Pteridophytes, $31 \%$ were Monocotyledons and $66 \%$ were Dicotyledons. There are 79 species that occur in $\geq 4$ relevés and which do not form appreciable clusters, and have been left out of the formal phytosociological description. However, all species are included in Online Appendix 1. The average number of species per plot is 14.16 (s.d. 6.56), minimum 4, maximum 32. There are seven sub-communities and variants with the same numbers of relevés, diagnostic, constant and dominant species. Accordingly, only the sub-communities have been described and named whilst ignoring the variants. There are 18 variants which have different diagnostic, constant and dominant species, which have been named. Subsequently, there are 13 unique subcommunities, 18 variants, 11 communities and four major communities which form the syntaxonomical classification presented in Online Appendix 1. 


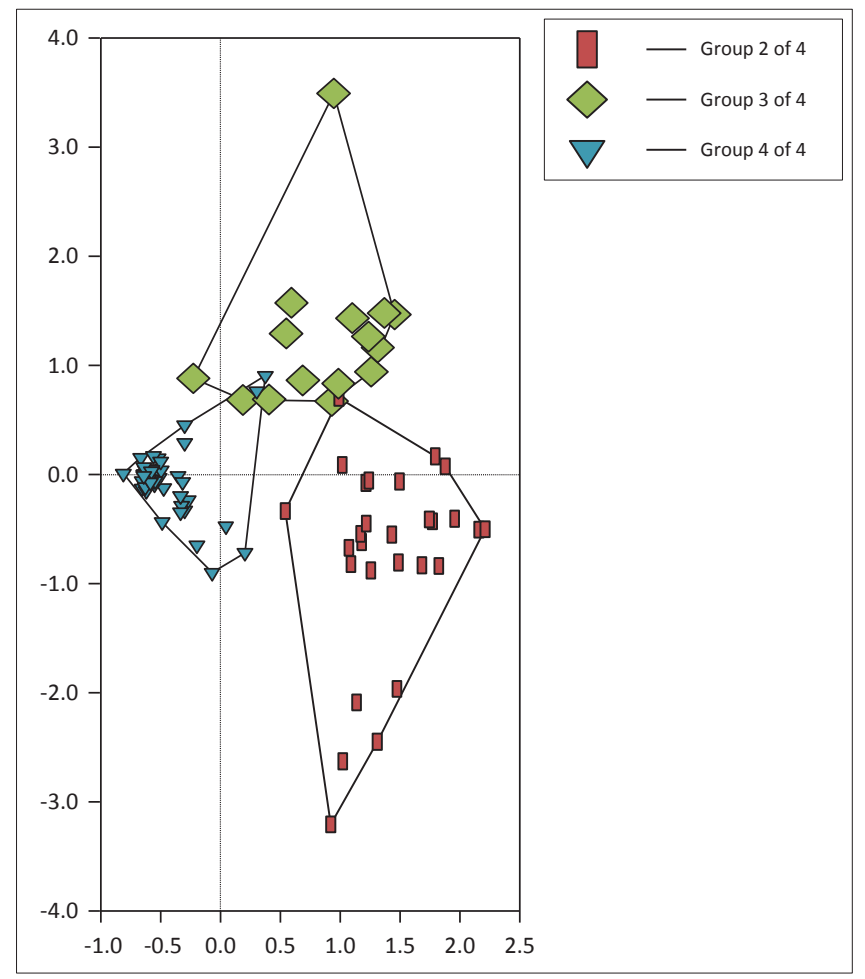

Source: Authors' own creation

Note: Groups 2, 3 and $4=$ Major communities 2, 3 and 4

FIGURE 5: Correspondence analysis with wetlands (Group 1) removed to show more clearly the gradients typifying Groups 2, 3 and 4.

\section{Gradient analysis}

TWINSPAN produced four major communities representative of four different habitats (Figures 4 and 5). These are:

- Major community 1: Wetland grass and forblands.

- Major community 2: Sheet rock grass and forblands.

- Major community 3: High-altitude alpine grassland.

- Major community 4: High-altitude alpine fynbos grassland.

Figure 4 shows outliers representing 11 relevés, all of which comprise major community 1, wetlands. Relevés 94, 91, 92 and 90 have the highest values and form major community 3 , which is the wettest of all habitats and is comprised of obligate wetland species: Aster erucifolius, Crassula dependens, Crassula gemmifera, Limosella grandiflora, Limosella vesiculosa, Pentaschistis airoides and Rhodohypoxis rubella (Online Appendix 1), which includes Aponogeton junceus found in deep, water-filled pools. Relevés 101, 102 and 103 represent major community 2, a mix of forbs favouring moist, shallow, wet rock or gravel areas, whilst relevés 97, 98, 99 and 100, which constitute major community 1 , have the dominant grass Pentaschistis airoides and the wetland forb Limosella vesiculosa, which is found in ephemeral or temporary wetlands and can withstand desiccation, high salinity and alkalinity and extreme temperatures of freezing and thawing (Heilmeier et al. 2005). Major community 1 ephemeral wetlands possibly dry up during June, July and August, the 3 driest months in the alpine region of the Drakensberg (Mucina \& Rutherford 2006). Major community 1 wetlands represent a gradation of wetland habitats, from deep pools (community 1; species group B, Online Appendix 1) to seasonal, shallow rocky seeps (community 2; species group C, Online Appendix 1) to semipermanent or ephemeral pools (community 3; species group D, Online Appendix 1). Limosella grandiflora (species group $\mathrm{D}$, Online Appendix 1) is an angiosperm, poikilohydric plant indicative of vernal or ephemeral pools (Figure 3), similar to inselbergs in Namibia and Zimbabwe (Heilmeier et al. 2005; Mokuku 1991) and described by Hillard and Burtt (1987) in the northern Drakensberg.

In Figure 4, the tight clustering of relevés 79-61 constitutes major community 2, and forms a decreasing gradient overlaid by relevés 81 through 96 to 61 . The habitat of sheet rock shallow soils is confirmed by the dominant species Scirpus ficinioides, a facultative wetland species (Marneweck \& Kotze 1999), and the diagnostic species Crassula peploides. Grasses forming major community 2 are the two facultative wetland species Festuca caprina and Koeleria capensis (Marneweck \& Kotze 1999). Additionally, within major community 2, the three grasses favouring seeps or seasonally inundated wetland habitats are Pentaschistis exserta, Polevansia rigida and Styppeiochloa gynoglossa (GibbsRussell et al. 1991). These sheet rock shallow soil habitats are found on all inselbergs, as shown in Figures 4 and 5, where group 2 represents major community 2, group 3 represents major community 3 (high-altitude alpine grasses) and group 4 represents major community 4 (high-altitude fynbos grasslands).

The results from Figures 4 and 5 show habitat and plant affinities associated throughout the six inselbergs whilst also showing separation into discrete clusters centred on each inselberg.

\section{Describing the plant communities}

All clusters are named in the Discussion and fully listed in the Online Appendix 1.

Major community 1, Rhodohypoxis rubella (wetland grass and forblands), which consists of 11 relevés, contains nine species (five monocots, four dicots) of which eight are endemic or near-endemic, high-latitude Afromontane/ DAC species with Rhodohypoxis rubella the diagnostic species (75.8\% abundance) as well as providing 100\% constancy. It is comprised of three communities. Community 1 has the diagnostic species Limosella vesiculosa (100\%) and the constant species Pentaschistis airoides and Rhodohypoxis rubella. Community 2 has no diagnostic species whilst constant species are Aster erucifolius, Crassula dependens (the only non-endemic DAC taxon), Rhodohypoxis rubella and the shrub Clutia nana (67\% constancy). Community 3 has the diagnostic species Aponogeton junceus (86.2\%) and Limosella grandiflora (80.9\%), with constant species Aponogeton junceus and Crassula gemmifera (75\%) and Limosella grandiflora and Rhodohypoxis rubella (100\%). All species provide limited cover/abundance with the shallow, seasonally inundated wetlands on gravel or sheet rock outcrop substrate. 
Major community 2, Scirpusficinioides-Crassulapeploides (sheet rock grass and forblands) is comprised of two communities, five sub-communities and eight variants. This major community has limited cover/abundance from all species with the diagnostic species Crassula peploides present in 54\% of 28 relevés. The vegetation is comprised of $61 \%$ monocots (18 species) and 13 dicots of which 3 are Crassulaceae (Online Appendix 1). The sedge Scirpus ficinioides is the dominant species. The two communities are community 2.1 (22 relevés) with Scirpus ficinioides the dominant species (71\% presence), and community 2.2 (5 relevés) which has no dominant species. The diagnostic species is Ficinia cinnamomea ( $88.8 \%$ presence), with constant species Clutia nana, Felicia linearis, and Oxalis obliquifolia. Species composition and habitat may suggest that major community 2 represents a gradient of vegetation types in transition between wetland habitat (major community 1) and alpine grassland (major community 3 ).

Sub-community 2.1.1, Crassula peploides - Rhodohypoxis rubella (wet grassland), is composed of two facultative wetland species. It has three variants (Online Appendix 1), is comprised of 9 relevés, and has $78 \%$ constancy of both wetland species. It has limited cover/abundance of all species and consists of scattered, low plants including the alpine grasses Polevansia rigida, Pentaschistis exserta, Koeleria capensis (variant 2.1.1.1) and Pentaschistis airoides (variant 2.1.1.3). Forbs and geophytes include endemic and nearendemic DAC taxa (Online Appendix 1).

Sub-community 2.1.2, Scirpus ficinioides - Styppeiochloa gynoglossa (alpine grassland), consists of five relevés, dominated by the sedge Scirpus ficinioides and defined by the DAC-endemic grass Styppeiochloa gynoglossa. In comparison with the previous sub-community it has a reduced presence of wetland species (Online Appendix 1), with variant 2.1.2.2 defined by the endemic forbs Glumicalyx montanus, and variant 2.1.2.3 defined by Helichrysum pagophilum.

Sub-community 2.1.3, Erica dominans - Polevansia rigida (Erica alpine grassland), consists of eight relevés and has three variants (Online Appendix 1), with Erica dominans having $88 \%$ consistency, and the first appearance of any Erica species. There are only two wetland species, Crassula peploides and Rhodohypoxis baurii, both of which have low presence. Three additional medium to tall alpine bunchgrasses, Festuca caprina (variant 2.1.3.2), Eragrostis caesia and Merxmuellera drakensbergensis (variant 2.1.3.3), occur.

Sub-community 2.2.1, Clutia nana - Hesperantha baurii (Forbland), with three relevés, and sub-community 2.2.2, Erica algida - Erica glaphyra (Heathland), with two relevés, contain only 16 species, 12 of which comprise the phytosociological classification. The graminoids, forbs and geophytes are small, low species, including the two Erica species Erica algida (DAC near-endemic) and Erica glaphyra (DAC endemic).

Major community 3 has three communities, two subcommunities and no variants. It is named the Pentaschistis exserta-Merxmuellera stricta (high-altitude alpine grassland), defined and dominated by Pentaschistis exserta, and includes Pentaschistis airoides (community 3.1), Cyperus schlechteri, Festuca caprina and Merxmuellera stricta (community 3.2). Community 3.3 is dominated and defined by ericaceous fynbos shrubs Erica dominans, Passerina montana, Cliffortia nitidula and Helichrysum trilineatum, with the alpine grass Merxmuellera stricta having limited cover/abundance. There are a total of 45 species of which 35 form the syntaxonomical classification; 11 of those are endemic and 10 near-endemic DAC taxa. Of the six grasses, one is endemic (Pentaschistis exserta), three are near-endemic (Eragrostis caesia, Pentaschistis airoides and Pentaschistis basutorum), with Festuca caprina and Merxmuellera stricta Afromontane species. All species are montane, using $\mathrm{C}_{3}$ metabolism, with only Eragrostis caesia (near-endemic) using the $\mathrm{C}_{4}$ pathway. Of the three sedges, Cyperus schlechteri and Schoenoxiphium schweickerdtii are nearendemic. Of the 14 forbs, 6 are endemic, 4 near-endemic and 4 widespread. Of the seven geophytes, four are endemic (Eucomis schijffii, Moraea alticola, Ornithogalum sephtonii and Sebaea spathulata). Of the five shrubs, one is endemic (Erica dominans), two are near-endemic (Helichrysum trilineatum, Macowania sororis) and the other two are montane fynbos.

Major community 4, Merxmuellera drakensbergensis Helichrysum trilineatum (high-altitude alpine fynbos grassland), is the most widespread vegetation type and comprises $46 \%$ of the vegetation found on all six inselbergs. There are three diagnostic species: the sedge Scirpus falsus, the shrub Helichrysum trilineatum (the tallest plant on the inselbergs) and the montane bunch grass Merxmuellera drakensbergensis. Constant species include Helichrysum trilineatum, Scirpus falsus, Merxmuellera drakensbergensis and Schoenoxiphium schweickerdtii. Dominant species are Erica dominans, Erica glaphyra, Merxmuellera disticha, Merxmuellera drakensbergensis, Passerina drakensbergensis and Scirpus falsus. Major community 4 has three communities, five subcommunities and eight variants (Online Appendix 1). Ten Erica species were identified: Erica aestiva, Erica dissimulans, Erica dominans, Erica flanaganii, Erica glaphyra, Erica thodei, all endemic to the Drakensberg, Erica algida and Erica alopecurus, both near-endemic, Erica maesta and Erica reenensis, both montane species also occurring in the Eastern Cape (Carbutt \& Edwards 2006). However, only Erica dominans and Erica glaphyra occurred with significant presence $( \pm 45 \%-49 \%$ respectively), with Erica thodei providing 29\% presence and 69\% constancy (Online Appendix 1). Excluding Erica, a total of 19 other fynbos shrubs or dwarf shrub species were recorded, of which Helichrysum trilineatum $(81.6 \%$ cover/abundance) is the dominant shrub, growing up to $2.5 \mathrm{~m}$ tall on Cathkin Peak. Other fynbos shrubs include Euryops decumbens (16\%), Erica montanus, Macowania glandulosa, Macowania sororis (Asteraceae), Muraltia alticola, Muraltia flanaganii, Muraltia montana (22.4\%), Polygala hottentotta (Polygalaceae), Cliffortia browniana, Cliffortia filicaulis, Cliffortia filicauloides, Cliffortia nitidula (Rosaceae), Anthospermum basuticum (55.5\%), Anthospermum hispidulum, Anthospermum monticola (Rubiaceae), Gnidia aberrans, Passerina drakensbergensis (16\%) and Passerina montana (Thymelaceae). 
The following three communities comprise major community 4: community 4.1, Scirpus falsus - Anthospermum basuticum (fynbos shrubland), with 11 relevés, two sub-communities and two variants, community 4.2, Erica glaphyra - Helichrysum trilineatum (Erica alpine grassland), with 24 relevés, two sub-communities and eight variants, and community 4.3, Merxmuellera drakensbergensis - Schoenoxiphium schweickerdtii (alpine grassland), with 14 relevés and two sub-communities (Online Appendix 1, species group R).

Community 4.1, Scirpus falsus - Anthospermum basuticum (fynbos shrubland), has the sedge Scirpus falsus as the dominant species and the DAC-endemic shrub Anthospermum basuticum as the defining species. It has two sub-communities: sub-community 4.1.1, Macowania glandulosa-Disa crassicornis (fynbos shrubland) and sub-community 4.1.2, Scirpus falsus Anthospermum basuticum, which is defined by a high cover/ abundance of the common sedge Scirpus falsus and has a lack of a unique species clustering.

Community 4.2, Erica glaphyra - Helichrysum trilineatum (alpine grassland), is the largest cluster (22 relevés) with 90\% presence of Erica glaphyra, which is also the dominant species. It is defined by Helichrysum trilineatum ( $82 \%$ constancy) and represents the widespread, dominant vegetation type on all inselbergs. It has two sub-communities: sub-community 4.2.1, Schoenoxiphium filiforme - Euryops montanus (fynbos), with three variants, and sub-community 4.2.2, Erica dominans - Schoenoxiphium schweickerdtii (heathland), with five variants. Sub-community 4.2 .1 is dominated by the endemic sedge Schoenoxiphium filiforme, and the cluster is defined by Euryops montanus, a DAC endemic. Erica glaphyra has 100\% constancy and high cover/abundance values associated with this sub-community in contrast with sub-community 4.2.2., which is dominated by Erica dominans (96\% constancy) and a concomitant reduced presence of Erica glaphyra. This mutual exclusion is also seen with the two sedges, Schoenoxiphium filiforme (67\% constancy in sub-community 4.2 .1 and $0 \%$ in sub-community 4.2.2) and Schoenoxiphium schweickerdtii (44\% constancy in sub-community 4.2 .1 and $90 \%$ in subcommunity 4.2.2).

The last community to the right on the syntaxonomic table (Online Appendix 1), community 4.3, Merxmuellera drakensbergensis - Schoenoxiphium schweickerdtii (alpine grassland), is dominated by the tall, rhizomatous, endemic grass Merxmuellera drakensbergensis with 100\% constancy and cover/abundance of $30 \%->70 \%$ of relevés. It is so dominant that it has almost totally excluded all other alpine grasses, fynbos families, for example Ericaceae, and the tall fynbos shrubs, for example Passerina, Cliffortia, Euryops and Helichrysum trilineatum. This could be a combination of two factors; it is found on deep soil and is a large, tufted grass which would out-compete smaller species.

Some plants were found to be present throughout many of the relevés in major community 4 , but with limited cover/ abundance. They include six forbs, namely Othonna burttii, Scabiosa columbaria, Craterocapsa tarsodes, Helichrysum infaustum, Helichrysum bellidiastrum and Alepidea pusilla. Other widespread forbs occurring with limited cover/ abundance found in major communities 2, 3 and 4 include Rhodohypoxis baurii (absent from major community 1), Psammotropha obtusa and Oxalis obliquifolia. The facultative wetland species Rhodohypoxis rubella, which dominates and defines major community 1 , also occurs scattered throughout other relevés in major communities 2 and 4 .

\section{Discussion}

\section{Classification}

The results from the phytosociological analysis indicate the inselberg vegetation has four major communities, 11 communities, 13 sub-communities and 18 variants (Online Appendix 1). Overlap exists with sub-communities and variants. The name designated for each cluster is for the highest order unit, whilst ignoring those of lower rank (Online Appendix 1). The names are:

Major community 1, Rhodohypoxis rubella, Wetland Grass and Forblands

Community 1.1, Limosella vesiculosa - Pentaschistis airoides, Wetland

Community 1.2, Crassula dependens - Aster erucifolius, Wetland

Community 1.3, Limosella grandiflora - Aponogeton junceus, Wetland

Major community 2, Crassula peploides - Polevansia rigida, Sheet Rock Grass and Forblands

Community 2.1, Scirpus ficinioides - Pentaschistis exserta, Grassland

Sub-community 2.1.1, Crassula peploides - Rhodohypoxis rubella, Wet Grassland

Variant 2.1.1.1 Koeleria capensis

Variant 2.1.1.2 Eucomis schijffii

Variant 2.1.1.3 Pentaschistis airoides

Sub-community 2.1.2, Scirpus ficinioides - Styppeiochloa gynoglossa, Alpine Grassland

Variant 2.1.2.1 Glumicalyx montanus

Variant 2.1.2.2 Helichrysum pagophilum

Sub-community 2.1.3, Erica dominans - Polevansia rigida, Alpine Grassland

Variant 2.1.3.1 Clutia nana

Variant 2.1.3.2 Festuca caprina

Variant 2.1.3.3 Styppeiochloa gynoglossa

Community 2.2, Ficinia cinnamomea-Felicia linearis, Heathland 
Sub-community 2.2.1, Clutia nana - Hesperantha baurii, Forbland

Sub-community 2.2.2, Erica algida - Erica glaphyra, Heathland

Major community 3, Pentaschistis exserta-Merxmuellera stricta, High-Altitude Alpine Grassland

Community 3.1, Pentaschistis airoides - Helichrysum pagophilum, Alpine Grassland

Community 3.2, Festuca caprina - Erica dominans, Alpine Grassland

Sub-community 3.2.1, Cyperus schlechteri - Glumicalyx goseloides, Alpine Grassland

Sub-community 3.2.2, Pentaschistis basutorum - Hebenstretia dura, Alpine Grassland

Community 3.3, Passerina montana - Cliffortia nitidula, Fynbos Shrubland

Major community 4, Merxmuellera drakensbergensis Helichrysum trilineatum, High-Altitude Alpine Fynbos Grassland

Community 4.1, Scirpus falsus - Anthospermum basuticum, Fynbos Shrubland

Sub-community 4.1.1, Macowania glandulosa-Disa crassicornis, Fynbos Shrubland

\section{Variant 4.1.1.1 Merxmuellera disticha}

\section{Variant 4.1.1.2 Erica reenensis}

Sub-community 4.1.2, Scirpus falsus - Anthospermum basuticum, Fynbos Shrubland

Community 4.2, Erica glaphyra - Helichrysum trilineatum, Alpine Grassland

Sub-community 4.2.1, Schoenoxiphium filiforme - Euryops montanus, Fynbos

Variant 4.2.1.1 Helichrysum albo-brunneum

Variant 4.2.1.2 Erica dissimulans

Variant 4.2.1.3 Cliffortia filicauloides

Sub-community 4.2.2, Erica dominans - Schoenoxiphium schweickerdtii, Heathland

Variant 4.2.2.1 Passerina drakensbergensis

Variant 4.2.2.2 Erica maesta

Variant 4.2.2.3 Dimorphotheca jucunda

Variant 4.2.2.4 Moraea alticola

\section{Variant 4.2.2.5 Merxmuellera stricta}

Community 4.3,Merxmuelleradrakensbergensis-Schoenoxiphium schweickerdtii, Alpine Grassland

Sub-community 4.3.1, Helichrysum montanum - Sebaea spathulata, Forbland

Sub-community 4.3.2, Glumicalyx goseloides - Oxalis obliquifolia, Wet Meadow

Major community 1 only has a single diagnostic species, Rhodohypoxis rubella, with constancy of 75 and no dominant species. There are no other species which occur with $> \pm 50 \%$ dominance or constancy (Online Appendix 1), thus a single species is used to name it.

The wetland vegetation consists of 11 relevés with nine species of which only Pentaschistis airoides occurs with any significant presence. It constitutes largely aquatic forbs and contributes $10 \%$ to the total vegetation surveyed. The highaltitude bogs, mires and peatlands described by Killick (1963, 1978a, 1978b, 1990), Hillard and Burtt (1987) and Hill (1996) and found on the escarpment top in Lesotho and the Mont-aux-Source/Tugela Falls area show floristic affinities with major community 1, Rhodohypoxis rubella (wetland) and to a lesser extent major community 2, Scirpus ficinioides - Polevansia rigida (alpine grassland). Aquatic taxa include Aponogeton, Crassula, Limosella and Rhodohypoxis on wet gravel plains and seeps.

Major community 2, Crassula peploides - Polevansia ridida (sheet rock grass and forblands), occurring on gravel seeps, has limited cover/abundance of most species and, after major community 1 , is lowest in species richness and contributes $39 \%$ of the total relevés. The shallow soils, gravel plains and sheet rock would appear to be the limiting factor responsible for the low growth form and limited species numbers and presence. The scattered, open nature vegetation is problematic in naming major community 2. Polevansia rigida was selected as the primary name as it had the highest cover/abundance and constancy out of all other species for all 28 relevés (Online Appendix 1). Monocots comprise 61\% of the diagnostic, constant and dominant species for major community 2, constituted by 31 species, 18 are monocots and 13 are dicots of which 3 are Crassulaceae. No carnivorous plants were found, unlike at Platberg, where Urticaceae and Droseraceae species formed distinct communities (Brand, Du Preez \& Brown 2013). Carnivorous plants from both these families are reported to be significant components of shallow soil and ephemeral flush vegetation communities occurring on inselbergs in the Ivory Coast (Porembski \& Barthlott 1997).

Major community 3, Pentaschistis exserta - Merxmuellera stricta (high-altitude alpine grassland), is dominated by and contains the majority of the $\mathrm{C}_{3}$ high-altitude, medium to small bunch grasses, Pentaschistis airoides, Pentaschistis basutorum, 
Festuca caprina and Merxmuellera stricta, which was chosen as the second syntaxonomic name (Online Appendix 1) as it has a $54 \%$ presence and cover/abundance, greater than the other five co-dominant species. The fynbos shrubs, best represented in community 3.3, include Cliffortia nitidula, Erica dominans, Macowania sororis, Passerina montana with the forbs Glumicalyx goseloides, Hebenstretia dura, Helichrysum album, Helichrysum sutherlandii, Helichrysum pagophilum and Helichrysum trilineatum (26\%, cover/abundance) the only nonfynbos shrub. Geophytes include Eucomis schijffii, Gladiolus longicollis, and Ornithogalum sephtonii; all high-altitude DACendemic taxa. Of significance is that no Themeda triandra was found whilst both Festuca costata and Festuca caprina have very limited occurrence, unlike the Themeda-Festuca alpine veld of Acocks (1988). Additionally, Chrysocoma ciliate, described as common and with increased occurrence on overgrazed areas (Acocks 1988), was found in only one relevé with ' + ' cover.

Major community 4, Merxmuellera drakensbergensis Helichrysum trilineatum (high-altitude alpine fynbos grassland) represents the vegetation common to and found on all inselbergs. The dominant plants are alpine $\mathrm{C}_{3}$ grasses combined with Helichrysum trilineatum, fynbos shrubs and the genus Erica which form heathlands. Major community 4 has species and physiognomic affinities with the uKhahlamba Basalt Grassland and the Drakensberg Afroalpine Heathland (Mucina \& Rutherford 2006). This cluster shares affinities with the lower-altitude Drakensberg-Amathole Afromontane Fynbos and the Lesotho Highlands Basalt Grassland (Mucina \& Rutherford 2006). Common dominant and prominent shrubs include the fynbos genera Cliffortia, Erica, Euryops, Helichrysum and Macowania. The altitude precludes any trees or shrubs over $2.5 \mathrm{~m}$ tall, which do occur at lower, more protected altitudes. This major community contains most of the endemic forbs and geophytes, which constitute numerous rare, threatened and endangered taxa. Sub-communities 4.1.1 and 4.2.1 are good representatives of this, as all three Orchidaceae, Disa crassicornis, Dracomonticola virginea and Satyrium longicauda Lindl. var. jacottetianum, occur in them. Other endemic geophytes include Albuca humilis, Eucomis schijffii, Moraea alpine, Moraea alticola, Ornithogalum sephtonii and Rhodohypoxis rubella.

All inselberg vegetation has a grass component, including most of the wetlands, rocky outcrops and gravel seeps, with 89 out of 103 relevés complying. Alpine grasses provide $98 \%$ cover/abundance and consistency throughout all four major communities, with the high-altitude vegetation dominated by $\mathrm{C}_{3}$ grasses. There are two $\mathrm{C}_{4}$ grasses: Polevansia rigida, 14 of the 28 relevés forming community 2.1, and Eragrostis caesia, occurring in 4 relevés and with low cover/abundance. Although there were only 27 graminoids (grasses and sedges) compared with 162 non-graminoid shrubs and forbs, they contribute $81 \%$ ( 82 plots) of the total cover of the 103 plots. The sedge Scirpus ficinioides was especially dominant in sub-communities 2.1.1 and 2.1.2, with the grass Pentaschistis exserta providing $93.5 \%$ presence in major community 3 (14 of 15 relevés). Dominant graminoid species varied from community to community, with Merxmuelleradrakensbergensis, Scirpus falsus and Schoenoxiphium schweickerdtii the most dominant (major community 4, 98\% average cover). The monotypic alpine grass Styppeiochloa gynoglossa, endemic to South Africa, is dominant in community 2.2 and subcommunity 4.1.2. Community 2.2 is defined by Ficinia cinnamomea, and Ficinia gracilis is dominant for variants 4.2.2.2 and 4.2.2.3 (80\% cover). Festuca costata occurs in only nine plots with only a ' + ' value. This is contrary to its reported occurrence and dominance used by Acocks (1988) to define the Themeda-Festuca alpine veld and which Mucina and Rutherford (2006) state defines the core of the DAC of Endemism. Of the 16 grass species (from nine genera), all are $\mathrm{C}_{3}$ except for Polevansia rigida, the only mat-forming, stoloniferous, rhizomatous grass, and Eragrostis caesia. The presence of Eragrostis caesia, which is a short to medium height (450 mm - $600 \mathrm{~mm}$ ) densely tufted grass, unlike other Eragrostis species, may be explained by the same temperature protection - thermal microclimate created by dense or large tussock growth form of Merxmuellera drakensbergensis and Merxmuellera stricta (Körner 2003; Tieszen et al. 1979). This same physiognomic, large-tussock grass is exhibited by another $\mathrm{C}_{4}$ grass, Andropogon amethystinus, which forms large tussocks, found on the Aberdares and Mt. Kenya above $3000 \mathrm{~m}$, and which has the same growth characteristic as Eragrostis caesia (Tieszen et al. 1979).

Plant physiological adaptation to alpine conditions can be seen in the large tufted grasses Merxmuellera, Pentaschistis, Festuca, Eragrostis caesia, Styppeiochloa gynoglossa; the filiform leaves of the sedges and forbs Cyprus schlechteri, Ficinia cinnamomea, Scirpus ficinioides, Schoenoxiphium filiforme, Schoenoxiphium schweickerdtii; the forbs Felicia linearis and Thesium pallidum; both tall and low cushion-shaped shrubs Helichrysum trilineatum, Cliffortia, Erica, Macowania sororis, Passerina; low tufts Anthospermum basuticum and Muraltia. It is also displayed by the pubescence of many forbs, Arctotis arctotoides, Berkheya rhapontica, Craterocapsa tarsodes, Dimorphotheca jucunda, Gazania krebsiana, Geranium multisectum, Glumicalyx goseloides, Helichrysum album, Helichrysum sutherlandii, Helichrysum pagophilum, and Senecio othonniflorus. Succulents and geophytes, plants with below-ground bulbs or corms, are two other adaptations to alpine conditions. Succulent plants found are Delosperma sphalmanthoides and Othonna burttii and geophytes include Albuca polyphylla, Disa crassicornis, Dracomonticola virginea, Eucomis schijffii, Hesperantha baurii, Ledebouria ovatifolia, Moraea alticola, both species of Rhodohypoxis and Sebaea spathulata Sebaea thodeana (Hedberg 1964; Körner 2003; Masao et al. 2013).

The high-altitude wetland community dominated by sedges and described by Hill (1996) has affinities with major communities 3 and 4 . The common sedges are Scirpus ficinioides and Schoenoxiphium filiforme. Two dominant grasses of Hill's high-altitude wetland community are Merxmuellera drakensbergensis and Pentaschistis oreodoxa, not found in the inselberg wetlands, but components of major community 4 . 
From Hill's (1996) description of the high-altitude wetland community, it shows more species and vegetation affinities with major community 4 , the alpine grasslands, than with wetlands on the inselbergs.

Of all regions in the Drakensberg, the inselbergs may be regarded as showing no anthropogenic influence from grazing, ploughing or fire, which does occur but is lighting induced. There is limited human presence: climbers have built cairns on most of the peaks, there are log books on Sentinel and Cathkin Peak, a bovine skull - probably a cow placed as vulture food - and the metal top of a smoke grenade was found on Cathkin, and tourists visit Inner and Outer Horn via helicopter; however, human impact is negligible, unlike the heavily impacted, overgrazed, hoof-eroded adjacent escarpment in Lesotho.

\section{Syntaxonomical classification}

Despite the broad treatment of the southern Africa vegetation by Mucina and Rutherford (2006), large parts of South Africa still remain to be surveyed in detail using phytosociological methods. There is still much work to be done before South Africa reaches the level of vegetation analysis, classification and description which currently exists in Europe. Consequently, the syntaxonomical plant associations presented use the standard system in current use in South Africa (Brown et al. 2013), that is, community, subcommunity and variant, which are analogous with alliance, association and sub-association, the original designations used by Braun-Blanquet (1964), and discussed by Westhoff and Van der Maarel (1980).

This article does not attempt to place the plant communities into a formal syntaxonomical classification of the established hierarchy of nomenclature and existing abstract categorisations of the European Zurich-Montpellier system (MuellerDombois \& Ellenberg 1974; Weber, Moravec \& Theurillat 2000). This survey encompasses 103 relevés, sampled on six inselbergs with a combined surface area of only 31.9 ha. It is felt that this survey does not give sufficient representation to cover the vegetation of the extensive alpine region of the Drakensberg. It would be appropriate for a larger-scale survey, which incorporates plots on the Escarpment adjacent as well as further north and south of the inselbergs, to be conducted. This would provide sufficient data to assign formal syntaxonomic ranks and names to the floristic clusters. The descriptions presented in this survey should be considered as a starting point.

\section{Conservation and climate change}

Papers on inselbergs in the Free State (Brand et al. 2010; Du Preez 1991) have provided suggestions to assist decision-makers to design policies and provide protection for vegetation, relict plant populations and endemic taxa found only on inselbergs. As part of the biodiversity plan for Free State, the Department of Economic Development, Tourism and Environmental Affairs (DETEA) has started the process of identifying inselbergs and making suggestions on a provincial scale to best manage and protect them (N. Collins [DETEA], pers. comm., 03 May 2012). In KwaZulu-Natal (KZN), which shares a common provincial boundary with the Free State, the protection of inselbergs is assured as part of the uKhahlamba-Drakensberg Park World Heritage Site Management Plan (Ezemvelo KZN Wildlife 2011). The management plan also stipulates on-going research to fill gaps in ecosystem function and reduce the risk of making incorrect management decisions. All World Heritage Sites require a protected area management plan as defined in Article 1 of the World Heritage Convention Act (No. 49 of 1999) (see https://www.environment.gov.za/sites/default/files/ legislations/world_heritage_conventionact49.pdf), and which is incorporated in South African national legislation to protect biodiversity. KZN is also in the process of developing its Buffer Policy (Forster 2007) to further protect the high mountains and their peaks (Ezemvelo KZN Wildlife 2011). As the first survey of these inselbergs, this article can make a contribution to the practical application of the KZN Protected Areas Management Plan.

Rising carbon dioxide levels with the concomitant increase in temperature will affect the composition and structure of alpine plant communities (Körner 2003), and particularly grasses which use the $C_{3}$ metabolic pathway, which are the most vulnerable to increase in temperature. The predicted effects are a drastic decrease in $\mathrm{C}_{3}$ grasses, as well as a decrease in the Drakensberg alpine vegetation in both area and number of vegetation units (Mucina \& Rutherford 2006). The alpine vegetation is embedded in the grassland biome and is defined as high-altitude Drakensberg grassland, a subdivision of the grassland biome (Mucina \& Rutherford 2006). A detailed phytosociological map has not been made of the vegetation above $2900 \mathrm{~m}$. Predictions are thus broad based and are extrapolations, which suggest an increase in woody components and a decrease in numbers of frost days and rainfall (Mucina \& Rutherford 2006).

Peters (1992) predicted that a $3{ }^{\circ} \mathrm{C}$ increase in global temperature would be equivalent to a $500 \mathrm{~m}$ upward shift in altitudinal zones. The threat posed by global warming to the world's alpine regions, including the Drakensberg, will cause a significant reduction in the distribution of plants, and change their structure and composition, forcing some taxa to higher altitudes (Taylor 1996), whilst those DAC endemics and $\mathrm{C}_{3}$ grasses already found at altitude will face the threat of total loss of habitat. For inselbergs - such as Platberg, which at its highest point is $2394.4 \mathrm{~m}$, below the critical altitude of $2500 \mathrm{~m}$ (Taylor 1996) - the loss of the taxa could be potentially catastrophic.

\section{Conclusion}

This article is a first attempt at a phytosociological analysis and vegetation description of high-altitude alpine plant communities in the Drakensberg, which, using ordination methods, identified four different habitats. It is unknown how species numbers and cover in these habitats may change seasonally as a result of decrease in rainfall during the 
drier season. The overriding ecological factor is prolonged freezing, the effect of high altitude, followed by high rainfall and, undoubtedly, soil composition and its depth, which play an important part in lower amplitude ecological factors responsible for species richness and diversity. This also confirms within community plant affinities as well as the broader landscape level vegetation clustering.

Legislation is in place to protect the inselbergs on the Drakensberg Escarpment as the Free State Province is in the process of drafting a provincial biodiversity strategy to specifically protect inselbergs.

\section{Acknowledgements}

The fieldwork was supported by the National Geographic Committee for Research and Exploration (grant \# 7920-05), without which funds the study would not have been possible. The Principle Investigator thanks the Maluti Drakensberg Transfrontier Project and the KwaZulu/Natal Conservation Staff for assistance with the fieldwork and plant identification. Photographs are courtesy of Richard Lechemere-Oertel, Boyd Escort and Rob Scott-Shaw, who also helped with plant identification in the field and at the Donald Killick Herbarium (CPF). The excellent maps of the study sites where composed by Heidi Snyman of Ezemvelo KZN Wildlife.

\section{Competing interests}

The authors declare that they have no financial or personal relationship(s) that may have inappropriately influenced them in writing this article.

\section{Authors' contributions}

R.F.B. (University of South Africa) was the project leader and principle author, N.C. (Free State Department of Economic, Tourism and Environmental Affairs) provided theoretical input and processed the data in Juice, and P.J.d.P. (University of the Free State) contributed 53 relevés and edited the syntaxonomic table presented as Online Appendix 1.

\section{References}

Acocks, J.P.H., 1988, Veld types of South Africa, 3rd edn., Memoirs of the Botanical Survey of South Africa No. 57, National Botanic Gardens/Botanical Research Institute, Pretoria.

Barthlott, W., Gröger, A. \& Porembski, S., 1993, 'Some remarks on the vegetation of tropical inselbergs: Diversity and ecological differentiation', Biogéographica 69, 105-124.

Brand, R.F., Du Preez, P.J. \& Brown, L.R., 2010, 'A floristic analysis of the vegetation of Platberg, Eastern Free State, South Africa', Koedoe 52(1), Art. \#710, http://dx.doi. org/10.4102/koedoe.v52i1.710

Brand, R.F., Du Preez, P.J. \& Brown, L.R., 2013, 'High altitude montane wetland vegetation classification of the Eastern Free State, South Africa', South African
Journal of Botany 88, 223-236. http://dx.doi.org/10.1016/j.sajb.2013.07.011

Braun-Blanquet, J., 1964, Pflanzensoziologie, Grundzüge der Vegetationskunde, 3rd edn., Springer, Vienna. http://dx.doi.org/10.1007/978-3-7091-8110-2

Brown, L.R., Du Preez, P.J., Bezuidenhout, H., Bredenkamp, G.J., Mostert, T.H.C. \& Collins, N.B., 2013, 'Guidelines for phytosociological classification and description of vegetation in southern Africa', Koedoe 55(1), http://dx.doi.org/10.4102/ koedoe.v55i1.1103

Burke, A., 2001, 'Determinants of inselberg floras in arid Nama Karoo landscapes', Journal of Biogeography 28, 1211-1220. http://dx.doi.org/10.1046/j.1365 2699.2001.00623.x

Burke, A., 2002, 'Plant communities of a Central Namib inselberg landscape', Journal of Biogeography 13(4), 483-492.
Burke, A., 2004, 'From plains to inselbergs: Species in special habitats as indicators of climate change?', Journal of Biogeography 31, 831-841. http://dx.doi. org/10.1046/j.1365-2699.2003.00984.x

Carbutt, C. \& Edwards, T.J., 2006, 'The endemic and near-endemic angiosperms of the Drakensberg Alpine Centre', South African Journal of Botany 72, 105-132. http://dx.doi.org/10.1016/j.sajb.2005.06.001

Du Preez, P.J., 1991, A syntaxonomical and synecological study of the vegetation of the South-Eastern Orange Free State and related areas with special reference to Korannaberg, PhD thesis, University of the Orange Free State, Bloemfontein.

Ezemvelo KwaZulu-Natal Wildlife, 2011, Concept development plan: UKhahlambaDrakensberg Park World Heritage Site, Ezemvelo KwaZulu-Natal Wildlife, Pietermaritzburg.

Forster, C.W., 2007, 'Specifications and methodology for the establishment of the buffer zone to the uKhahlamba Drakensberg World Heritage Site Park', draft final report for KZN Wildlife, Pietermarizburg.

Gauch, H.G., 1982a, Multivariate analysis in community ecology, Cambridge University Press, Cambridge. http://dx.doi.org/10.1017/CBO9780511623332

Gauch, H.G., 1982b, 'Noise reduction by eigenvector ordinations', Ecology 63(6), 1643-1649. http://dx.doi.org/10.2307/1940105

Germishuizen, G., Meyer, N.L., Steenkamp, Y. \& Keith, M. (eds.), 2006, A checklist of South African plants, South African Botanical Diversity Network, Report No. 41, SABONET, Pretoria.

Gibbs-Russell, G.E., Watson, L., Koekemoer, M., Smook, L., Barker, N.P., Anderson, H.M. et al., 1991, Grasses of Southern Africa, Memoirs of the Botanical Survey of South Africa No. 58, National Botanic Gardens/Botanical Research Institute, Pretoria.

Hedberg, O., 1964, 'Features of afroalpine plant ecology', Acta Phytogeographica Suecica 49, 1-144.

Heilmeier, H., Durka, W., Woitke, M. \& Hartung, W., 2005, 'Ephemeral pools as stressful and isolated habitats for the endemic aquatic resurrection plant Chamaegigasintrepidus', Phytocoenologia 35(2-3), 449-468. http://dx.doi. org/10.1127/0340-269X/2005/0035-0449

Hennekens, S.M. \& Schaminée, J.H., 2001, 'TURBOVEG: A comprehensive database management system for vegetation data', Journal of Vegetation Science 12 589-591. http://dx.doi.org/10.2307/3237010

Hill, M.O., 1979, TWINSPAN - a FORTRAN program for arranging multivariate data in an ordered two-way table by classification of the individuals and attributes, Section of Ecology and Systematics, Cornell University, Ithaca, New York, USA.

Hill, T.R., 1996, 'Description, classification and ordination of the dominant vegetation communities, Cathedral Peak, KwaZulu-Natal Drakensberg', South African Journal of Botany 62, 263-269.

Hillard, O.M. \& Burtt, B.L., 1987, The botany of Southern Natal Drakensberg, National Botanical Gardens, Cape Town.

Huntley, B.J. (ed.), 1989, Biotic diversity in Southern Africa: Concepts and conservation, Oxford University Press, Cape Town.

Killick, D.J.B., 1963, An account of the plant ecology of the Cathedral Peak area of the Natal Drakensberg, Memoirs of the Botanical Survey of South Africa No.34 Government Printer, Pretoria.

Killick, D.J.B., 1978a, 'The Afro-alpine region', in M.J.A. Werger (ed.), Biogeography and Ecology of Southern Africa, pp. 515-560, Junk, The Hague. http://dx.doi. org/10.1007/978-94-009-9951-0_12

Killick, D.J.B., 1978b, 'Notes on the vegetation of the Sani Pass area of the Southern Drakensberg', Bothalia 12, 537-542.

Killick, D.J.B., 1990, A field guide to the flora of the Natal Drakensberg, Jonathan Ball, Johannesburg.

Körner, C., 2003, Alpine plant life: Functional plant ecology of high mountain ecosystems, Springer, Berlin. http://dx.doi.org/10.1007/978-3-642-18970-8

Legendre, P. \& Legendre, L., 1998, Numerical ecology, Elsevier Science, Amsterdam.

Lepš, J. \& Hadincová, V., 1992, 'How reliable are our vegetation analyses?', Journal of Vegetation Science 3(1), 119-124. http://dx.doi.org/10.2307/3236006

Marneweck, G.C. \& Kotze, D., 1999, 'Appendix W6: Guidelines for delineation of wetland boundary and wetland zones', Resource directed measures for protection of water resources: Wetland ecosystems, Department of Water Affairs and Forestry, viewed 12 November 2013, from https://www.dwa.gov.za/Documents/ Forestry, viewed 12 November 2013 , from $h$
Policies/WRPP/Wetland\%20Ecosystems.htm

Masao, C.A., Gizaw, A., Piñeiro, R., Tusiime, F.M., Wondimu, T., Abdi, A.A. et al., 2013, 'Phylogeographic history and taxonomy of some afro-alpine grasses assessed based on AFLPs and morphometry: Deschampsia cespitosa, $D$. angusta and Koeleria capensis', Alpine Botany 123(2), 107-122.

Mokuku, C., 1991, 'Classification of the alpine plant communities of the MjikaLisiu', MSc thesis, Department of Biological Sciences, University of Zimbabwe, Harare.

Mucina, L. \& Rutherford, M.C., 2006, The vegetation of South Africa, Lesotho and Swaziland, Strelitzia 19, South African National Biodiversity Institute, Pretoria.

Mueller-Dombois, D. \& Ellenberg, H., 1974, Aims and methods of vegetation ecology, Wiley, New York.

Parmentier, I., Oumorou, M., Porembski, S., Lejoly, J. \& Decocq, G., 2006, 'Ecology, distribution, and classification of xeric monocotyledonous mats on inselbergs in West Africa and Atlantic central Africa', Phytocoenology 36(4), 547-564. $\mathrm{http}: / / \mathrm{dx}$.doi.org/10.1127/0340-269X/2006/0036-0547 
Peters, R.L., 1992, 'Conservation of biological diversity in the face of climatic change', in R.L. Peters \& T.E. Lovejoy (eds.), Global warming and biological diversity, pp. 15-30, Yale University Press, New Haven, Connecticut.

Podani, J., 2006, 'Braun-Blanquet's legacy and the data analysis in vegetation science', Journal of Vegetation Science 17, 113-117. http://dx.doi. org/10.1111/j.1654-1103.2006.tb02429.x

Porembski, S. \& Barthlott, G.B., 1997, 'A species poor tropical sedge community Afrotrilepis pilosa mats on inselbergs in West Africa', Nordic Journal of Botany 16(3), 239-246. http://dx.doi.org/10.1111/j.1756-1051.1996.tb00222.x

Porembski, S. \& Brown, G., 1995, 'The vegetation of inselbergs in the Comoe National Park (Ivory Coast)', Conservatoire et Jardin Botanicues de Geneve 50(2), 351-365

Porembski, S., Szarzynske, J., Mund, J-P. \& Barthlott, W., 1996, 'Biodiversity and vegetation of small-size inselbergs in a West African rain forest (Taï, Ivory Coast)', Journal of Biogeography 23, 47-55. http://dx.doi.org/10.1046/j.1365 2699.1996.00982.x

Porembski, S., Fisher, E. \& Biedenger, N., 1997, 'Vegetation of inselbergs, quartzitic outcrops and ferricretes in Rwanda and eastern Zaire (Kivu)', Bulletin du Jardin Botanique de l'Etat, Bruxelles 66, 81-95.

Seine, R., Becker, U., Porembski, S., Follman, G. \& Barthlott, W., 1998, 'Vegetation of inselbergs in Zimbabwe', Edinburgh Journal of Botany 55, 267-293. http://dx.doi. org/10.1017/S0960428600002195
Taylor, D., 1996, 'Mountains', in W.M. Adams, A.S. Goudie \& A.R. Orme (eds.), The physical geography of Africa, pp. 287-306, Oxford University Press, Oxford.

Tichý, L. \& Holt, J., 2006, Juice: Program for management, analysis and classification of ecological data, Program manual, Vegetation Science Group, Masaryk University, Brno.

Tieszen, L.L., Senyimba, M.M., Imbamba, S.K. \& Troughton, J.H., 1979, 'The distribution of $\mathrm{C}_{3}$ and $\mathrm{C}_{4}$ grasses and carbon isotope discrimination along an altitudinal and moisture gradient in Kenya', Oecologia 37(3), 337-350. http:// dx.doi.org/10.1007/BF00347910

Van Noort, S., Gardiner, A.J. \& Tolley, K.A., 2007, 'New records of Ficus (Moraceae) species emphasize the conservation of significance of inselbergs in Mozambique', South African Journal of Botany 73, 642-649. http://dx.doi.org/10.1016/j. sajb.2007.04.063

Weber, H.E., Moravec, J. \& Theurillat, J.P., 2000, 'International code of phytosociological nomenclature', Journal of Vegetation Science 11, 739-768. http://dx.doi. org/10.2307/3236580

Westhoff, V. \& Van der Maarel, E., 1980, 'The Braun-Blanquet approach', in R.H. Whitaker (ed.), Classification of plant communities, pp. 287-378, Kluwer Academic, The Hague.

Whitaker, R.H., 1980, Classification of plant communities, Kluwer Academic, The Hague. 